\title{
Calls for more independence for government medical officers
}

$\mathrm{P}$ hysicians are calling for Canada's chief medical officers of health to be given greater independence from provincial governments following the recent firing of New Brunswick's medical officer, Dr. Eilish Cleary, for reasons that remain unknown.

"The position is too important to allow people to be arbitrarily dismissed," says Dr. James Talbot, the former chief medical officer of health for Alberta. "We need to be sure they can speak out."

The New Brunswick Medical Society was alarmed by Cleary's firing and warned the government that it would strongly oppose the decision if there was any indication it was politically motivated. "New Brunswick's doctors stand behind any of our colleagues who raise an issue in the interest of patient safety or health promotion," said the society's president, Dr. John Whelan, in a letter to provincial Health Minister Victor Boudreau. "It is one of our enduring core principles, especially in an era where so few professionals speak out on important issues."

Cleary was placed on leave involuntarily in early November for what was described as a "personnel issue." On Dec. 7, she told CBC News she had been fired "without cause" because the government had concluded that "my particular skill set does not meet the needs of my employer." Cleary had been the province's medical officer since 2008 and spent much of the past year on secondment to the World Health Organization (WHO) to help fight the Ebola outbreak in West Africa.

There has been much speculation about the reason for Cleary's departure, and members of the opposition have asked the Liberal government to provide more details on the matter. Health Minister Victor Boudreau said he could not discuss personnel issues publicly, though did say the decision was not politically motivated. The New Brunswick Department of Health did not respond to a request for comment for this article.

At the time of her suspension, Cleary had been looking into the potential effects on human health of the herbicide glyphosate, used extensively in New Brunswick's forestry industry. The WHO's International Agency for Research on Cancer deemed glyphosate a "probable carcinogen" earlier this year. Ann Pohl, head of the Kent County chapter of the Council of Canadians, who asked Cleary to investigate the herbicide, says she would not be surprised if the firing was the result of political interference. "There's no way they can have someone with scientific rigour in that job and keep a lid on all the things the government wants to do," she says.

If the firing was indeed politically motivated, it wouldn't be the first time a Canadian public health official suffered such a fate. In 2002, Dr. David Swann, a medical officer of health with Palliser

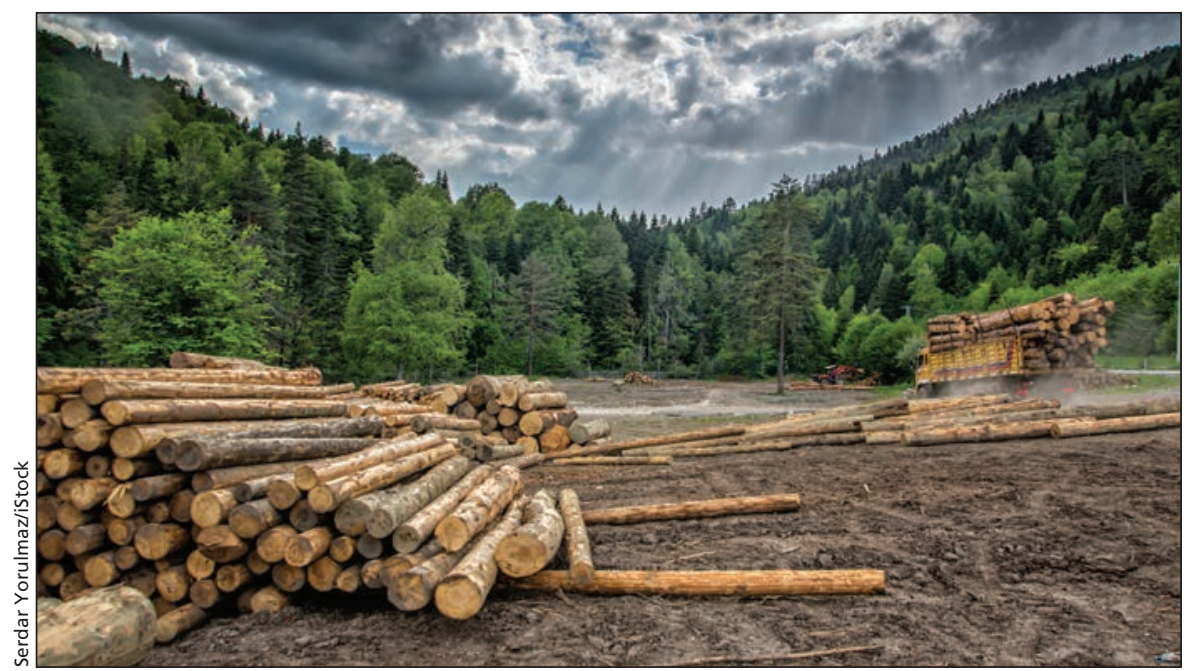

New Brunswick's former chief medical officer of health had been looking into the potential effects on human health of the herbicide glyphosate, used extensively in the forestry industry.
Health and Headwaters Health regions in southern Alberta, was fired after calling on the government to take action on climate change and air pollution. Currently, three provinces (Alberta, Ontario and New Brunswick) are seeking new chief medical officers of health because the previous incumbents were fired or their contracts were not renewed.

Cleary's work has created controversy before. In 2012, the previous Conservative government initially appeared reluctant to publish her report on the potential public health effects of shale gas operations. This drew criticism from the opposition, and the government later said it would at least publish parts of the report.

Talbot says there are always going to be instances when a government and its medical officer will have to balance competing interests, such as when advice to address public health matters are deemed too expensive or clashes with party ideology. But a medical officer's first obligation is to the public, not political masters, says Talbot.

The New Brunswick Medical Society has been pushing for legislation to formally recognize and protect that independence. In 2014, the provincial Liberal Party, then in opposition, endorsed the idea and made it one of their election promises. But there has been no movement on the file since the party took power more than a year ago. "We strongly supported your positive stance in this regard," Whelan reminded Boudreau in his letter. "We have been waiting patiently for this clear commitment to be acted upon."

Only British Columbia, Ontario and the federal government have legislation in place to protect chief medical officers from political interference and give them the ability to communicate directly with the public on any health issue they see fit. Having that kind of political protection and independence is vital for maintaining public trust in the public health system, says Talbot. "Without trust, public health is incapable of functioning. Nothing loses trust faster than going against the values that people hold important, like honesty." — Brian Owens, St. Stephen, NB

CMAJ 2016. DOI:10.1503/cmaj.109-5213 